Lengyel Attila ${ }^{1}$

\title{
Magyarország egészségturisztikai desztinációként való márkázása: aszinkronitási problémák
}

\author{
Lengyel, Attila \\ Branding Hungary as a Health Tourism Destination: Asynchrony Problems
}

\section{Összefoglaló:}

Egy ország vonzó turisztikai desztinációként való márkázása hosszú távú és meglehetősen komplex feladat. Számos brand értékelö rendszer létezik és egymástól akár jelentösen is eltérö metodológiát használnak arra, hogy indexálják az ország márkákat. A Bloomberg márkaindexáló rendszer 2014 európai rangsorában Magyarország a 20., míg a Future Brand értékelö rendszerben a 23. helyet foglalja el. Ezek a helyezések relatíve gyenge márkateljesítményre utalnak és egy olyan integrált imázs építést tesznek szükségessé, mely független a változó politikai eröstruktúráktól. A sikeres márkázás egyik kulcsfontosságú eleme a különböző szinteken megvalósuló marketing eröfeszítések szinkronizálása. Az aszinkron kommunikáció és stratégiák imázs érzékelési zavarokhoz, következésképpen a márka gyengüléséhez vezetnek. Jelen tanulmány néhány olyan aszinkron problémát vizsgál, melyek Magyarország mint egészségturisztikai desztináció márkázásában tetten érhető.

Kulcsszavak: egészségturisztikai desztináció, márkázás, desztináció márkázás, aszinkronitás problémák, integrált imázsépítés

\begin{abstract}
:
Branding a country as an attractive tourism destination is an extremely complex and long-term endeavour. There are several brand assessment systems using diverse methodology for creating brand indices for countries. In the Bloomberg brand indexing system Hungary is ranked 20th in Europe and by Future Brand 23rd in 2014. These placements are indicators of a relatively poor performance of Hungary as a nation brand and warrant an integrated image building effort independent from the changing political power structure. There are certain basic principles to adhere to in branding a tourism destination be it settlement, regional or country level. One of the keys to succesful branding is synchronising marketing efforts on different levels. Asynchronous communication and strategies lead to confusion in image perception, hence the weakening of the brand. The present paper aims to examine some of the asynchronies in the branding of Hungary as a health tourism destination.

Keywords: health tourism destination, branding, destination branding, asynchrony problems, integrated image building
\end{abstract}

\section{A MÁRKAÉPÍTÉSI ASSZINKRON PROBLÉMÁKRÓL ÁLTALÁBAN}

A desztináció márka építésének sikerében meghatározó tényező, hogy ne legyen diszkrepancia a jelenlegi, kívánatos, tervezett és kommunikált márkakép elemek között. (Nagyné molnár 2012, Piskóti et al 2002). A szerzők által említett gyakori aszinkron problémák a következők:

- A jelenlegi és a kívánatos kép márkaépítésben érintett szereplők részéről tapasztalható eltérő megítélése.

\footnotetext{
${ }^{1}$ Főiskolai tanársegéd, Szolnoki Főiskola Turizmus-, Térség és Társadalomfejlesztési Tanszék, 5000 Szolnok Tiszaligeti sétány 14.
} 
- A jelenlegi márka-teljesítmény és a döntéshozók által kialakított kívánatos kép közötti eltérés.

- A döntéshozók által kialakított kívánatos kép és a belső célcsoportok elvárásai közötti

- eltérése.

- A jelenlegi önkép és a kívánatos önkép közötti eltérés.

- A külső célcsoportok jelenlegi megítélésének és jövőbeli elvárásainak eltérése.

- A döntéshozók által kialakított kívánatos kép és a külső célcsoportok által elvárt kívánatos

- külső kép közötti eltérés.

- A kívánatos önkép és a kívánatos külső kép közötti eltérések.

- Az objektív tények megfelelőek, de nem sikerül kellően elismertetni az erősségeket.

- A kommunikáció erősebb, mint az objektív tartalom.

- A valós teljesítmény és a márkaépítésben érintett szereplők eltérő megítélése.

- Eltérő megítélés a valós teljesítmény és annak az önképi (belső) megjelenése kapcsán.

- A valós teljesítmény és annak külső képben való megjelenése közti különbség.

- A jelenlegi önkép és a jelenlegi külső kép eltérő megítélése.

Jelen tanulmány a fenti aszinkron problémák közül néhány olyan területet elemez, melyek gyengíthetik Magyarország, mint desztináció márka építésének és kommunikációjának hatékonyságát.

2. A DÖNTÉSHOZÓK ÁLTAL KIALAKÍTOTT KÍVÁNATOS KÉP ÉS A DÖNTÉSHOZÓK ÁLTAL VÁZOLT IMÁZS STRATÉGIAI PRIORITÁSAI KÖZÖTTI ELTÉRÉS

A Gyógyító Magyarország Egészségipari Program (GYMEP), az Új Széchenyi Terv egyik alprogramja. Az új uniós tervezési szakaszt (2014-2020) lefedő stratégiai dokumentum azt az ambiciózus célt tǔzi ki, hogy Magyarország Európa egészségturisztikai központja legyen 2020-ra. Ehhez pozicionáló szlogenként a
„Gyógyító Magyarország” kifejezést használja. Az imázs építésnél, a márkázásnál alapvető a hitelesség (Szondi, 2010). Ha az ország gyógyító potenciállal bíró jelenlegi erőforrásaira gondolunk (termálvíz, gyógyfürdők, wellness létesítmények, gyógyszeripar, orvosok), akkor a "Gyógyító Magyarország”, mint imázs összegző és pozicionáló szlogen megalapozottnak túnik. Másfelől viszont egy ország imázsának, márkájának elsődleges közvetítői és létrehozói az ott élő emberek. A dokumentum egy fél mondat erejéig helyesen mutat rá: „Az egészségipar eredményei jótékonyan hatnak a lakosság egészségi állapotára, ezzel az ország egyik legfontosabb problémájára ad választ ...". Nézzük meg, hogy a program, milyen célokat tǔz ki:

$$
\begin{aligned}
& \text { - - Elmaradott térségek felzárkóztatása } \\
& \text { - - A geotermikus energia komplex } \\
& \text { hasznosítási lehetősége } \\
& \text { - - Természeti adottságok védelme, a } \\
& \text { minőség garantálása } \\
& \text { - - Az ország versenyképességének tartós } \\
& \text { növelése } \\
& \text { - - Tudásfejlesztés }
\end{aligned}
$$

A célokhoz tartozó rövid magyarázatokban nem jelenik meg az ország egészségi állapotának javítása, annak ellenére, hogy előzóleg a dokumentum ezt (helyesen) az ország egyik legsúlyosabb gondjának nevezi. Egyfelől tehát szeretnénk, ha az ország egy "Gyógyító" helyként pozícionálódna a fejekben (itthon és külföldön), azzal is tisztában vagyunk, hogy az ország egészségi állapota rossz (hogy mennyire, később még utalunk rá), ugyanakkor a célrendszerbe az egészségi állapot javítása nem kerül be.

\section{A VALÓS TELESÍTMÉNY ÉS A MÁRKAÉPÍTÉSBEN ÉRINTETT SZEREPLŐK ELTÉRŐ MEGÍTÉLÉSE}

A minőségi turizmusfejlesztés várható eredményei részben a GYMEP egy mondat erejéig még tesz utalást: „A szabadidő eltöltésének vonzóbb, kedvezőbb feltételei hatékonyabb rekreációt tesznek lehetővé, ami a munkaképesség, illetve az egészségi állapot 
javulásában is tetten érhetővé válik." A KSH adatai szerint a többnapos belföldi utazásokon résztvevők száma 2004 és 2007 közel 30\%-al nőtt. Ennek a megnövekedett belföldi turisztikai részvételnek a pozitív hatása viszont nem érhető tetten, ha megnézzük a 2004 és 2012 közötti OECD egészségügyi statisztikáit. $A$ belföldi turizmus növekedése önmagában valószínúleg nem képes jelentős változásokat generálni az egészségi állapot tekintetében. Tehát a valós teljesítmény és a márkaépítők megítélése között jelentős különbség mutatkozik.

\section{A JELENLEGI MÁRKA-} TELJESÍTMÉNY ÉS A DÖNTÉSHOZÓK ÁLTAL KIALAKÍTOTT KÍVÁNATOS KÉP KÖZÖTTI

\section{ELTÉRÉS}

A lakosság egészségi állapotának szemléltetésére nézzünk meg néhány $\mathrm{OECD}$ által közölt adatot az EU-hoz történő csatlakozásunk előtti időszakból, illetve ezzel összevetésként a közelmúltból. A táblázatban szereplő számok azt mutatják, hogy hányadikak vagyunk a 2003-ban és 2011-ben publikált adatok alapján a vizsgált OECD tagországok közül, valamint 2012-ben a vizsgált 27 EU tagállamból. Zárójelben a kutatásba bevont összes ország szerepel. A táblázat egy hét éves időszak két végpontját hasonlítja össze. Sajnos nem igazán beszélhetünk szignifikáns javulásról, hiszen a 2011-es kedvezőbb pozíciók esetében a vizsgált országok száma is jóval magasabb. Tudnak-e vajon azonosulni a Gyógyító Magyarország ország márkával egy olyan ország lakosai, akik a fenti adatokkal jellemezhető testi-lelki állapotban vannak?

\begin{tabular}{|c|c|c|c|}
\hline Indikátorok & 2003 OECD & 2011 OECD & $2014 \mathrm{EU}$ \\
\hline Várható élettartam & 29. (30) & 33. (40) & 23. (28) \\
\hline $\begin{array}{l}\text { laschemiás szívbetegség } \\
\text { előfordulása/100.000 fő }\end{array}$ & 2. (26) & 4. (34) & $5(28)$ \\
\hline Rák okozta halálozás/100.000 fő & 1. $(26)$ & 1. (34) & 1. $(28)$ \\
\hline Öngyilkosság/100.000 fő & 1. $(26)$ & 3. (34) & 2. (28) \\
\hline $\begin{array}{l}\text { Alacsony születési súlyú csecsemők } \\
\text { \%-os aránya }\end{array}$ & 2. (26) & 7. $(40)$ & 5. $(28)$ \\
\hline Korai elhalálozás/100.000 fő & 1. $(26)$ & 3. (34) & 6. (28) \\
\hline $\begin{array}{l}\text { Magukat egészségesnek tartók \%-os } \\
\text { aránya }\end{array}$ & 23. (26) & 29. (34) & 23. (28) \\
\hline Gyógyszerfogyasztás/fó/év & 9. (22) & 16. (32) & 5. (28) \\
\hline
\end{tabular}

1. táblázat - OECD és EU egészségügyi indikátorok Forrás: Health at a glance 2003, 2011, 2014 adatok alapján saját szerkesztés

„Orvos, gyógyítsd meg magadat.", idézi Jézus Lukács evangéliumában az egyik korabeli szólást. Az országnak elsődlegesen saját magát kell meggyógyítania, mindenekelőtt az itt élók számára kell gyógyító hellyé válnia. Ahogyan már említésre került, az országmárka építésben alapvető fontosságú a hitelesség. Ennek a hitelességnek a megteremtése itthon kezdődik (Harmath, 2011). Jelen formájában a vizionált imázs bizonyos szempontból a visszafelé elsülő fegyverhez hasonlatos, de hozhatnánk annak a túlsúlyos orvosnak a példáját is, aki az elhízás veszélyeiről beszél a televízióban.

\section{A JELENLEGI ÉS A KÍVÁNATOS KÉP MÁRKAÉPÍTÉSBEN ÉRINTETT SZEREPLŐK RÉSZÉRŐL TAPASZTALHATÓ ELTÉRŐ MEGíTÉLÉSE}

A „Think Hungary - More than expected” új ország promóciós imázs film, amit a londoni World Travel Market-on a világ legnagyobb turisztikai vásárán mutattak be, és a stratégiai dokumentum angolosított pozicionáló szlogene "Curing Hungary" (Gyógyító Magyarország) nem sok kapcsolatot mutat. A Gyógyító 
Magyarország Egészségipari Program (GYMEP) teljesen egyértelmúen egyfajta irányba kívánja pozícionálni az országot. Ha tételesen összevetjük ezen program két alprogramjának egyes prioritási területeit, és azt hogy az új imázs filmben (Think Hunagry - More than expected) milyen arányban kapnak ezek képi megjelenítést, akkor a következő \%-os értékeket kapjuk:

- Természeti gyógy tényezőkre épülő egészségturizmus - $20 \%$

- Orvosi szolgáltatásokon alapuló egészségturizmus - $0 \%$

- Helyi és térségi TDM szervezetek fejlesztése $-0 \%$

- TDM informatikai rendszer beszerzése - $0 \%$

- Geotermikus energia egészségipari hasznosítása - 0\%

- Növényházi kertészet - 0\%

- Szépségipar, kozmetikumok - 0\%

- Ásványvíz- és gyógyvízpalackozás-0\%

- Gyógyszeripar-0\%

- Orvosi múszergyártás - 0\%

- Biotechnológia, nanotechnológia - 0\%

Ahogyan látható a szaldó nem túl pozitív. Még ha az olyan stratégiai prioritásokat, mint a TDM rendszer fejlesztése, vagy a Növényházi alprogram, nem is vesszük figyelembe, akkor is óriási a szakadék a két közlés között. Miközben a GYMEP kihangsúlyozza, hogy a termálturizmus egyre inkább az orvosi szolgáltatásokkal csomagba rendezve piacképes, ez egy snitt erejéig sem jelenik meg a filmben. Talán megoldható lett volna, hogy az egyébként lényeges USP-k, mondjuk egy a GYMEP-ban megadott prioritásokra épülő vizuális és dramaturgiai kontextusba kerülnek bele.

\section{A JELENLEGI ÖNKÉP ÉS A KÍVÁNATOS ÖNKÉP KÖZÖTTI ELTÉRÉS}

Ahogyan korábban már megállapítást nyert, az ország márka építés során először is fel kell mérni a jelenlegi önképet, társadalmi és szakmai egyeztetés és konszenzus után kialakítani egy elérendő belső és külső imázst.
Ezen elérendő imázs célnak az emberekkel történő elfogadtatása után (Jenes, 2012) határozott és konkrét lépéseket tenni az imázst megalapozására a jelenlegi teljesítmény hatékonyabbá tételére. A konkrét változások és helyzet javulása erősíteni fogja a korábban konszenzussal elfogadott imázs célt, ami egy felfelé mozgó pozitív spirálként, még több erőt ad a cél felé vezető úton. Az elérendő imázs cél esetünkben a Gyógyító Magyarország és korábban azt is megállapítottuk, hogy elsősorban az imázs elsődleges hordozóinak és közvetítőinek, az itt élőknek kell a mostani siralmas egészségi (testi, lelki) állapotból egy olyan szintre jutni, ahol a lakosság döntő többsége jól és egészségesen érzi magát. A GDP, mint életminőséget mérő mutató mellett egyre nagyobb hangsúlyt kapnak a szubjektív jóllétet, az élettel való elégedettséget mérő komplex mutatók. Az OECD Better Life Index szerint az élettel való elégedettség alapján Magyarország a vizsgált 34 ország közül a 32, a Happy Planet Index szerint 2014-ben 151 ország közül a 104. Ezek a pozíciók jelentős elégedettségi problémákat sejtetnek. A következőkben két másik, a szubjektív jólléttel összefüggő OECD mutatót vizsgáljunk meg.

A 1. ábra azt mutatja, hogy a jövőbe vetett bizalom alapján a Magyarok 2012-ben az utolsó harmadban helyezkednek el, azon országok társaságában, ahol a szubjektív jóllét jelentősebb romlására számítanak öt éven belül. Ami legszorosabban kapcsolódik az egészséghez és a megálmodott imázs célhoz a 2. ábrán látható, ahol 50 és $60 \%$ között van azoknak az aránya, akik magukat egészségesnek gondolják. Európában ez a 4. legrosszabb eredmény. Érdekes ezt az ábrát a korábban látott 1. táblázattal összevetni. Az ottani objektív egészségügyi mutatók még ezt a minimális szubjektív egészségérzetet sem támasztják alá. Az ország tehát gyógyításra, gyógyulásra szorul. Lehet, hogy első körben az "Öngyógyító Magyarország" szlogen hitelesebb lenne. 


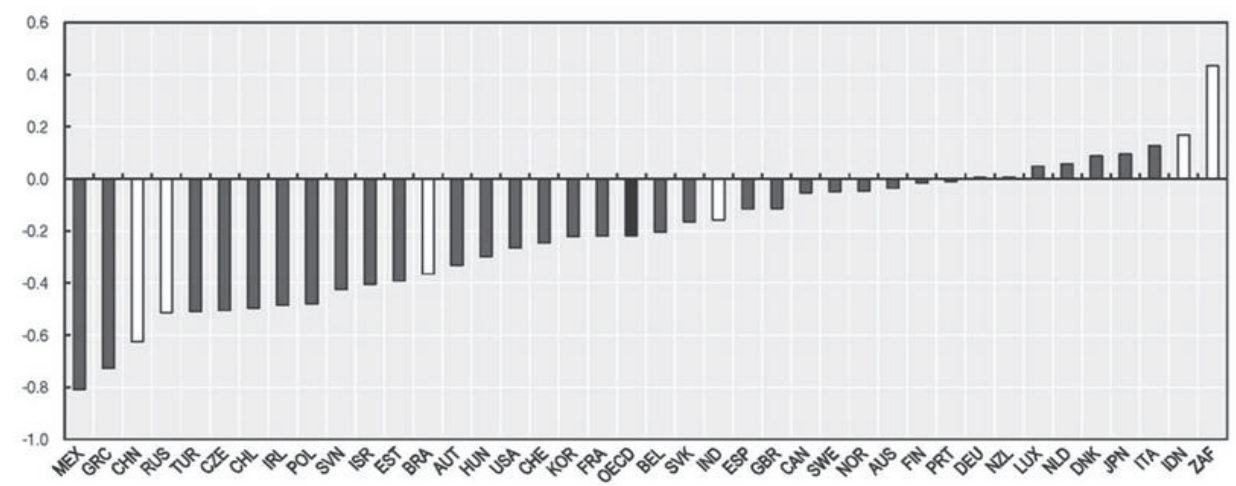

1. ábra - A szubjektív jóllét 2012-es és öt évvel későbbre remélt szintje közötti különbség

Forrás: OECD How is life? 2013

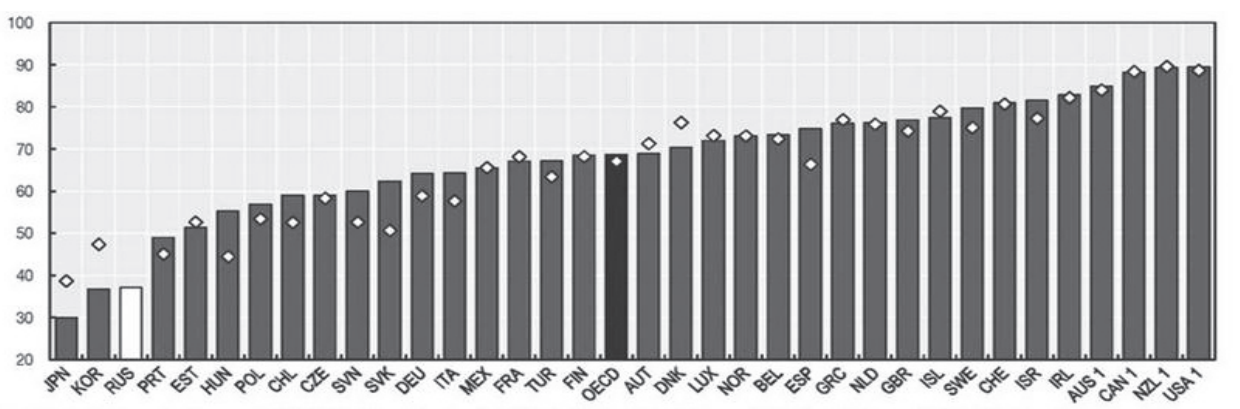

2. ábra - Magukat egészségesnek gondolók százalékos aránya

Forrás: OECD How is life? 2013

\section{A DÖNTÉSHOZÓK ÁLTAL KIALAKÍTOTT KÉP ÉS A KÜLSŐ KÉP KÖZÖTTI KÜLÖNBSÉG}

Itt a legfontosabb turisztikai küldőpiancuknak Németországnak a turistái körében 2006-ban a Turizmus Rt/TNS Hungary által végzett felmérés eredményeire szeretnék kitérni (frissebb kutatások nem állnak rendelkezésre). A német turisták csupán 4.9\%-a asszociál a gyógyfürdőkre Magyarországgal kapcsolatban. A több mint $20 \%$-os asszociációs értéket a „Budapest”, „Balaton”, „Puszta” szavak, míg a 10 \%-ot a "Szép tájak”, "Borok”, „Lovak”, "Gulyás" szavak érték el. Ez egy nagyon szerény kiindulási helyzet ahhoz az ambiciózus célhoz képest, ami szerint az ország Európa egészségturisztikai központja lesz 2020-ra. Fontos volna ennyi idő elteltével a jelentősebb küldőpiacok tekintetében reprezentatív felméréseket végezni a külső imázs percepció tekintetében. Végezetül megemlíthető még az a Nemzeti Turizmusfejlesztési Koncepcióban tényként kommunikált sztereotípia is, miszerint Magyarország egy vendégszerető nemzet. A WEF 2013-ra vonatkozó Tourism Competitiveness Report egyik kérdése a következő: „Mennyire látják szívesen a külföldi látogatókat az Ön országában?" (saját fordítás) A felmérésben a kérdésre adott válaszok alapján a vizsgált 140 ország közül Magyarország a 116. helyen van. Kirívó az eltérés. Tudni kell, hogy a World Economic Forum által kiadott turisztikai versenyképességet mérő jelentés a legrangosabb ilyen jellegű szakmai dokumentum globálisan. 


\section{8. ÖSSZEFOGLALÁS}

A globalizáció fokozódásával párhuzamosan, annak mintegy ellensúlyozásaképp megfigyelhető a nemzeti identitás megőrzésére irányuló társadalmi igények erősödése. Ez a tendencia az Európai Unióban is tetten érhető és egybecseng a stratégiai, hosszú távú turizmusfejlesztés prioritásaival, melyek közül az egyik legfontosabb a fokozódó globális versenyben az egyediség a desztinációk különlegességének hatékony menedzselése és a kialakított imázs márkaként történő kommunikációja. Az érdekek és érdekeltek sokféleségéből adódóan egy ország márkázása, imázsának tudatos felépítése sokrétú és hosszú távú feladatokat ró a közösségekre, lokális, regionális és nemzeti szinten egyaránt. A tényleges partnerségen alapuló márkaépítési tevékenység egyik kulcsfontosságú tényezője a márkával kapcsolatos régi, jelenlegi, tervezett, külső, belső percepciók, elvárások minden szinten történő összehangolása. A szinkron hiányában a márkázást és végeredményben a márkát gyengítő aszinkron folyamatok realizálódhatnak. Ezek közül villantott fel néhányat a jelen tanulmány abban a reményben, hogy a marketing kutatókat a témában kiterjedtebb kutatásra a döntéshozókat és érdekelteket pedig hatékonyabb márkaépítésre sarkalja.

\section{FELHASZNÁLT IRODALOM}

[1] Piskóti, I- Dankó, L.- Schupler, H. (2002): Régió- és településmarketing. KJK KERSZÖV Budapest

[2] Nagyné Molnár, M. (2012): Terület- térségmarketing /Elméleti jegyzet/. Új Széchenyi Terv

[3] Harmath, E. N. (2011): Magyarország a világ szemében - a Magyarország márka. Szakdolgozat, Budapest: BGF.

[4] Szondi, Gy. (2010): From image management to relationship building: A public relations approach to nation branding. Place Branding and Public Diplomacy. 6, pp. 333-343.

[5] Jenes, B., (2012): Theoretical and practical issues in measuring country image. Dimensions and measurement model of country image and country brand. PhD. Corvinus: Doctoral School of Business Administration 